\title{
Sciendo
}

PROCEEDINGS OF THE LATVIAN ACADEMY OF SCIENCES. Section B, Vol. 75 (2021), No. 1 (730), pp. 58-64.

DOI: $10.2478 /$ prolas-2021-0010

\section{COMPARISON OF FLUOROSCOPICALLY AND ARTHROSCOPICALLY ASSISTED VOLAR PLATING OF ARTICULAR DISTAL RADIUS FRACTURES}

\author{
Uldis Krustiņš $^{1,2, \#}$, Vadims Nefjodovs ${ }^{1,2}$, Diāna Bringina ${ }^{1}$, Aija Jaudzema ${ }^{2}$, \\ and Andris Jumtins ${ }^{3}$ \\ ${ }^{1}$ Centre of Microsurgery of Latvia, 410 Briviibas Av., Rīga, LV-1024, LATVIA \\ ${ }^{2}$ Rīga East University Hospital, 2 Hipokrāta Str., Rīga, LV-1038, LATVIA \\ 3 Trauma and Orthopaedic Department, Rīga Stradiṇš University, 22 Duntes Str., Rīga, Latvia, LV-1005, LATVIA \\ \# Corresponding author, uldis.krustins@mcl.Iv
}

Communicated by Aigars Pētersons

The article presents the results of a retrospective study that included 70 patients with intraarticular (AO Type C [Arbeitsgemeinschaft für Osteosynthesefragen]) distal radius fractures, who were treated using an arthroscopically assisted approach with volar locking plates or just a fluoroscopically assisted surgery. Thirty-seven of them were treated using volar locking plates using only fluoroscopically guided surgery and 33 patients were treated with the arthroscopically assisted fracture fixation method. Data of the patients who attended a full cycle of the postoperative observation within the first year after the surgery and postponed to the last visit 1 to 5 years after the surgery were included in the analysis for both groups. Postoperative analysis was carried out using X-ray assessment, clinical data, patient-rated wrist evaluation score, Gartland and Werley score, Modern Activity Subjective Survey of 2007 score, range of motion, grip, pinch and tripod pinch assessment at 1, 3, 6 and 12 months postoperatively. Despite the statistically significant differences found in a number of parameters during the follow-up period, there were no clinically relevant differences determined between the two methods in the long-term period. There was a greater arch of motions in extension and radial deviation in the arthroscopic surgery group. Duration of the surgery was longer in the arthroscopic surgery group, but comminuted or AO-C3 type fractures also were more often presented in this group. One complex regional pain syndrome occurred in the arthroscopic surgery group and two in the control group. None of patients suffered tendon ruptures, hardware migration or infections.

Key words: wrist arthroscopy, hand surgery, TFCC lesions, intercarpal ligament injuries, functional outcome.

\section{INTRODUCTION}

The increasing incidence of distal radial fractures may be attributed to an ageing population as well as the growing participation in outdoor pursuits of the younger population, which leads to high velocity accidents (Shukla et al., 2014). From $32 \%$ to $44 \%$ of these fractures nowadays are AO Type C fractures (Koo et al., 2013; Sander et al., 2018).

Application of volar compression plates for treatment of the articular distal radius fractures started in the late 1990s. Consequently, the popularity of volar angle stable plate fixation has increased, as has the number of implants avail- able on the market. Variations in plate design include adaptations to the shape and contour of the plate, the size and angle of the screws, the locking screw mechanism, and the type of plate material (von Recum et al., 2012). These plates are anatomically pre-shaped with a low-profile plate designed to minimise soft-tissue irritations and with a possibility for customised positioning of distal interlocking screws. A self-taping screw head design provides extra stability of the distal fragments and prevents the risk of late collapse. There are many studies showing that locked volar plates are well tolerated, allow early movement and maintain position for intra-articular fractures (Jupiter et al., 2009; Souer et al., 2010; Matschke et al., 2011). Superiority 
of volar plating over other treatment methods for distal radius fractures has been confirmed in many trials and scientific papers (Wright et al., 2005; Richard et al., 2011; Wilcke et al., 2011; Esposito et al., 2013; Williksen et al., 2013; Xie et al., 2013; Franceschi et al., 2015). Several articles claim that arthroscopic reduction of intra-articular fragments, as opposed to conventional methods, may improve outcomes (Doi et al., 1999; Freeland and Geissler, 2000; Ruch et al., 2004; Varitimidis et al., 2008; Ono et al., 2012; Abe, 2014), but others, that with regard to functional outcomes or radiographic parameters, however, arthroscopic reduction does not appear advantageous (Yamazaki et al., 2015; Selles et al., 2020). Since the diversity of opinions is still topical in the literature, we decided to compare our available results of treatment of articular distal radius fractures with volar locking plates.

This article presents a retrospective comparison of outcomes of the only fluoroscopically controlled method for fixation of the articular distal radius fractures and arthroscopically assisted reduction of intra-articular fragments. All surgeries were performed by the same hand surgeon and volar locking plates were used as a fixator of the fracture fragments.

\section{MATERIALS AND METHODS}

The study protocol was approved by the local ethical committee. The inclusion criteria were as follows: patients of both genders, at least 16 y.o. with only AO Type $\mathrm{C}$ fracture of one distal radius. Polytrauma patients, patients with bilat- eral distal radius fractures or previous fractures of the opposite wrist were not included in the study.

From March 2009 till December 2014, 58 AO Type C fractures were treated using different types of fracture fixation, including volar locking plates, k-wires or external fixator and K-wires, without arthroscopic assisted surgery. Thirtyseven of them were treated using volar locking plates. In 2015, this group of patients was observed and their functional outcomes, $\mathrm{X}$ rays, Patient-Rated Wrist Evaluation score (PRWE), Modern Activity Subjective Survey of 2007 (MASS07) and Gartland \& Werley scores recorded. Medical records of the hand therapist during the period of the rehabilitation also were collected. Complete lists of postoperative rehabilitation protocols, including late X-rays in the radiological database of the hospital, were collected for 27 patients and rehabilitation protocols with X-rays at least one year after the surgery, recorded in other resources for three more patients, creating a research group of 30 patients with follow-up from one to five years. Since January 2015, articular distal radius fractures were treated only with arthroscopically assisted surgeries. There were 75 AO C-type fracture surgeries performed till the end of the 2018 and 38 of them with volar locking plates. Thirty-three patients later attended all scheduled post-operative visits, and thus were included in the trial. This group was evaluated in 2019. The follow-up period of them was from one to three years.

The demographic data were comparable between the groups, but the incidence of the AO C-type fractures significantly differed (Table 1).

Table 1. Patient characteristics in the two study groups

\begin{tabular}{|c|c|c|c|}
\hline Variables & Arthroscopy & No arthroscopy & $p$-value \\
\hline Number of patients ( $\%$ of total number of patients) & $33(52.3 \%)$ & $30(47.6 \%)$ & $0.4^{\mathrm{c}}$ \\
\hline \multirow[t]{2}{*}{ Age, in years ${ }^{\mathrm{a}}$} & $40(19-64)$ & $\Uparrow 41(21-61)$ & $0.9^{\mathrm{d}}$ \\
\hline & ๆ $59(29-73)$ & @ $53(20-79)$ & $0.4^{\mathrm{d}}$ \\
\hline High energy trauma ( $\%$ of total number of patients) & $3(5 \%)$ & $7(11 \%)$ & $0.3^{\mathrm{c}}$ \\
\hline Dominant hand injured ( $\%$ of total number of patients) & $12(19 \%)$ & $16(25 \%)$ & $0.5^{\mathrm{c}}$ \\
\hline AO $\mathrm{C} 1$ fractures (\% of group) ${ }^{\mathrm{b}}$ & $5(15 \%)$ & $13(43 \%)$ & $0.001^{\mathrm{c}}$ \\
\hline AO C2 fractures (\% of group $)^{\mathrm{b}}$ & $8(24 \%)$ & $10(33 \%)$ & $0.08^{\mathrm{c}}$ \\
\hline $\mathrm{AO} \mathrm{C} 3$ fractures (\% of group $)^{\mathrm{b}}$ & $20(61 \%)$ & $7(23 \%)$ & $0.001^{\mathrm{c}}$ \\
\hline Time from accident till surgery, days ${ }^{\mathrm{a}}$ & $6(0-14)$ & $9(0-34)$ & $0.1^{\mathrm{d}}$ \\
\hline Ulnar styloid fracture & 18 & 19 & $0.1^{\mathrm{c}}$ \\
\hline
\end{tabular}

\footnotetext{
${ }^{a}$ Data is presented with the mean (range)

${ }^{\mathrm{b}}$ Fracture AO (Arbeitsgemeinschaft für Osteosynthesefragen) classification

c Chi-square test

d Independent T-test

§-male

- female
} 
Surgical technique. All surgeries were carried out by the same hand surgeon, experienced in wrist arthroscopy. Surgeries were performed under axillary block or general anesthesia and with the tourniquet inflated to between 280 and $320 \mathrm{mmHg}$. Surgeries were performed using the flexor carpi radialis approach and pronator quadratus muscle elevation. Fracture fixation was achieved with two different plates: Synthes $2.4 \mathrm{~mm}$ LCP distal radius system or Stryker VariAx plate (Fig. 1). Position of the fragments and plate was assessed by using intraoperative fluoroscopy and decision of additional fragment reposition or prevention of soft tissue lesions was made based on the experience of the surgeon. In arthroscopically assisted surgeries, once the fracture was preliminarily fixed with the plate, the wrist joint was assessed arthroscopically using the 3-4, 4-5 and 6R portals. In several cases additional portals, $6 \mathrm{U}$ and $1-2$, were used to remove blood clots and small articular fragments (Fig. 2). If articular step-offs or gaps were present, additional reposition and fixation with $\mathrm{K}$-wires was performed. Distal screws were inserted only after the arthroscopic inspection of the radiocarpal joint and a fluoroscopic confirmation of the correct position for the screws. If dorsal, ulnar or radial fragments, uncontrolled by the plate were detected, additional K-wires were inserted. These were cut under the skin and remained indwelling after the procedure. Associated soft tissue injuries, such as triangular fibrocartilage complex (TFCC) tear, damage of scapholunate or lunotriquetral ligaments, were assessed after the fracture had been

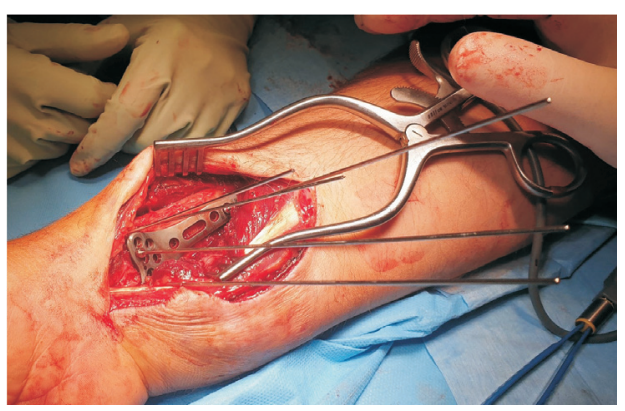

Fig. 1. Preliminary fixation of the volar locking plate.

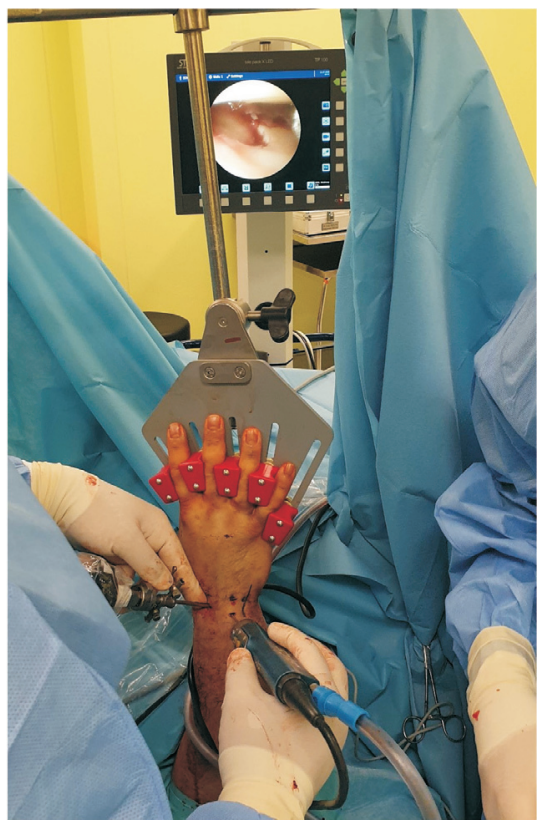

Fig. 2. Arthroscopic evaluation and additional fixation of fragments. stabilised. In several cases, debridement of the injured ligaments or TFCC was performed, as well as trans-articular fixation of the scapholunate and/or lunotriquetral joints with $\mathrm{K}$-wires, or application of peripheral sutures for TFCC tears. Bone-grafting was not performed (Krustins et al., 2019).

All arthroscopically assisted surgeries were performed using the dry arthroscopy technique recommended by Francisco del Pińal (Del Pinal, 2011).

Postoperative care. Patients were treated with a short plaster cast for two weeks followed by a removable short arm orthosis for approximately two weeks, when gentle active wrist motion could begin. Patients were advised to use a removable orthosis, if required. Standard exercises for finger motion were initiated immediately after the surgery. The first visit to the same hand therapist was scheduled for all patients two weeks after the surgery. All patients were instructed to perform additional exercises at home for a minimum of 30 minutes per day and visit a hand therapist on a weekly basis. Patients were recommended to use nonsteroidal anti-inflammatory drugs during the first week after the surgery and as required thereafter (Krustins et al., 2019).

Assessment. This was a retrospective study - a comparison of the results, achieved by the same hand surgeon, using the same implants for the same types of fractures, within a period of approximately ten years. The first group of patients was treated without optical visualisation of the joint surface, but the other group with arthroscopically assisted fracture evaluation and fixation. Change of the technique was determined by the improving wrist arthroscopy skills of the surgeon and growing number of the comminuted distal radius fractures sent to the University clinic from the regional health centres. The results of treatment were assessed with $\mathrm{X}$-ray examinations postero-anterior position in a $10^{\circ}$ tiltedview and lateral position in a $20^{\circ}$ tilted-view, subjective evaluation using the PRWE score (rating from 0 to 140 with a lower score representing a better result), MASS07 score (rating from 0 to 100 with a lower score representing a better result), and subjective and objective evaluation using the Gartland and Werley score (rating from 17.5 to 100 with a higher score representing a better result). Grip/pinch/tripod-pinch strength and ranges of motion (ROM) were also measured. Wrist mobility was tested using a goniometer, grip strength with Jamar dynamometer, and pinch and threepoint strength with a pinch gauge. Scheduled follow-up assessments were performed at $1,3,6$, and 12 months postoperatively by a hand therapist or by one of the senior orthopaedic surgeons if the hand therapist was not available. $\mathrm{X}$-ray assessment was performed by an independent radiologist.

Statistical analysis. Mean values and standard deviations were calculated in descriptive statistics. Chi-square tests revealed the equality of the research groups. Normality of data was checked with the Shapiro-Wilk test; the MannWhitney U test was applied for non-parametric data. An independent sample $\mathrm{T}$ test was used for parametric data. 


\section{RESULTS}

Demographic data of the research groups are presented in Table 1. Mean age of the patients was 51.3 years (ranged 19-79 years), but it differed between genders. Twenty patients $(61 \%)$ in the arthroscopy group had a C3 fracture, while in the control group only seven patients had a C3 fracture (23\%). Average surgery time was 90 minutes (ranged 30-155 minutes) in the arthroscopy group and 70 minutes (ranged 45-150 minutes) in the control group.

Incidence of additional soft tissue injuries and consequent surgical manipulations differed between the groups. Ten patients in the arthroscopic group had scapholunate ligament tears (Geissler grades II-IV), eight patients had Triangular fibro-cartilage complex (TFCC) tears, and five patients had both. Scapholunate joint trans-fixation with $\mathrm{K}$-wires with additional scaphocapitate joint fixation was performed in four patients with acute Geissler grade IV scapholunate ligament tears. Three patients underwent ulnar styloid fracture fixation with K-wires and tension bands due to TFCC and distal radioulnar joint instability.

Only four patients in the "no arthroscopy" group with additional soft tissue injuries were recognised. These included 2 TFCC and 2 scapholunate Geissler grade IV injuries. The treatment included closed reduction of scapholunate joint and trans-fixation with K-wires, as well as ulnar styloid fixation with $\mathrm{K}$-wires and tension band for distal radio-ulnar joint stabilisation.

The clinical dynamometric and goniometric parameters improved evenly over the period of 12 months (Fig. 3). Differences in subjective, objective and radiological parameters between both research groups are presented in Table 2. Statistically significant differences were observed in wrist extension, forearm pronation, as well as radial and ulnar deviation (Figs. 4-7). Patients treated with arthroscopy had slightly lower PRWE and MASS07 scores and higher Gartland \& Werley scores in the long-term period. A radiologically smooth distal radius joint surface was observed in 27 patients $(82 \%)$ in the arthroscopy group, while six (18\%) patients had radiological articular incongruity; in the control group 19 patients $(63 \%)$ had a radiologically smooth radius joint surface, while eight $(27 \%)$ patients had radiological irregularities.

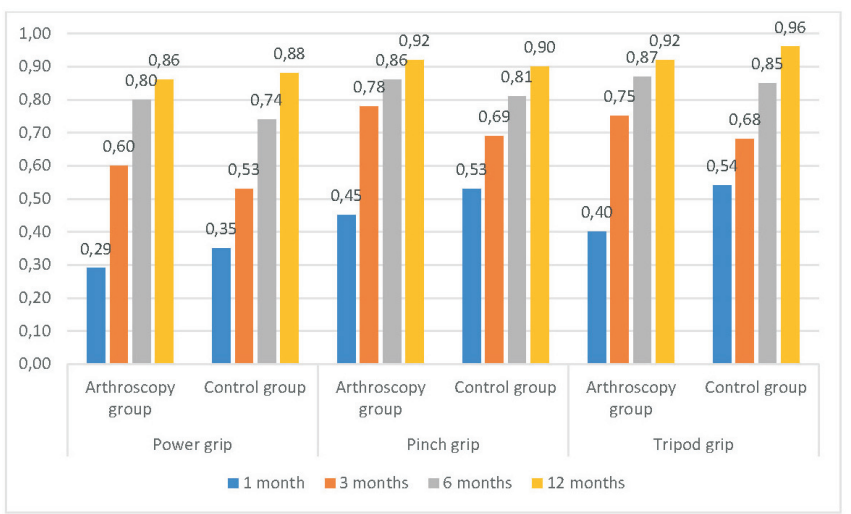

Fig. 3. Grip values during the first year after the surgery.
Table 2. Objective measurements, patient surveys and radiological data in one to five years follow-up period

\begin{tabular}{|c|c|c|c|}
\hline Variables & $\begin{array}{l}\text { Arthroscopy } \\
33 \text { patients }\end{array}$ & $\begin{array}{l}\text { No arthroscopy } \\
30 \text { patients }\end{array}$ & $p$-value \\
\hline Final follow-up, months ${ }^{\mathrm{f}}$ & $26.7(7.2)$ & $34.7(16.7)$ & $0.01^{\mathrm{d}}$ \\
\hline Power grip ${ }^{\mathrm{e}}$ & $86 \%(0.11)$ & $88 \%(0.06)$ & $0.5^{\mathrm{d}}$ \\
\hline Pinch grip ${ }^{\mathrm{e}}$ & $92 \%(0.08)$ & $91 \%(0.08)$ & $0.5^{\mathrm{d}}$ \\
\hline Tripod grip ${ }^{\mathrm{e}}$ & $92 \%(0.09)$ & $96 \%(0.06)$ & $0.06^{\mathrm{d}}$ \\
\hline Wrist flexion ${ }^{\mathrm{e}}$ & $84 \%(0.13)$ & $79 \%(0.11)$ & $0.1^{\mathrm{d}}$ \\
\hline Wrist extension ${ }^{\mathrm{e}}$ & $92 \%(0.11)$ & $80 \%(0.12)$ & $<0.0001^{\mathrm{d}}$ \\
\hline Forearm supination $^{\mathrm{e}}$ & $97 \%(0.07)$ & $94 \%(0.06)$ & $0.08^{\mathrm{d}}$ \\
\hline Forearm pronation $^{\mathrm{e}}$ & $99 \%(0.04)$ & $97 \%(0.04)$ & $0.02^{\mathrm{d}}$ \\
\hline Radial deviation ${ }^{\mathrm{e}}$ & $90 \%(0.10)$ & $77 \%(0.17)$ & $0.001^{\mathrm{d}}$ \\
\hline Ulnar deviation $^{\mathrm{e}}$ & $87 \%(0.10)$ & $80 \%(0.15)$ & $0.05^{\mathrm{d}}$ \\
\hline PRWE $^{\mathrm{f}}$ & $2.2(3.4)$ & $5(9.5)$ & $0.1^{\mathrm{d}}$ \\
\hline MASS $07^{\mathrm{f}}$ & $0.3(0.8)$ & $0.8(1.7)$ & $0.2^{\mathrm{d}}$ \\
\hline $\begin{array}{l}\text { Gartland \& Werley } \\
\text { score }^{f}\end{array}$ & $91.6(8.0)$ & $87.9(8.0)$ & $0.07^{\mathrm{d}}$ \\
\hline Radius inclination, of & $19.4(4.3)$ & $20(4.6)$ & $0.6^{\mathrm{d}}$ \\
\hline Radial height, $\mathrm{mm}^{\mathrm{f}}$ & $10.3(2.4)$ & $10.1(3.2)$ & $0.8^{\mathrm{d}}$ \\
\hline Volar tilt, ${ }^{\circ f}$ & $4.2(2.8)$ & $4.6(4.3)$ & $0.7^{\mathrm{d}}$ \\
\hline Ulnar variance, $\mathrm{mm}^{\mathrm{f}}$ & $-0.9(1.2)$ & $-1.0(1.8)$ & $0.9^{\mathrm{d}}$ \\
\hline $\begin{array}{l}\text { Smooth joint surface } \\
\text { (\% in group) }\end{array}$ & $27(81 \%)$ & $19(63 \%)$ & $0.7^{\mathrm{c}}$ \\
\hline \multicolumn{4}{|l|}{${ }^{\mathrm{c}}$ Chi-square test } \\
\hline \multicolumn{4}{|l|}{${ }^{\mathrm{d}}$ Independent $\mathrm{T}$-test } \\
\hline \multicolumn{4}{|c|}{$\begin{array}{l}\text { e Data is presented with mean measures percentages compared with } \\
\text { healthy hand }(\mathrm{SD})\end{array}$} \\
\hline${ }^{\mathrm{f}}$ Data is presented with & 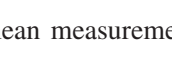 & & \\
\hline
\end{tabular}

PRWE, Patient-Rated Wrist Evaluation survey

MASS07, Modern Activity Subjective Survey of 2007

${ }^{\circ}$ - angle degrees

$\mathrm{mm}$ - millimetres

Complications. One patient (3\%) in the arthroscopically assisted group developed a complex regional pain syndrome (CRPS), but she was successfully treated conservatively by physical therapy and intravenous corticosteroid injections. In the control group we found two cases $(6.7 \%)$ of CRPS, and patients partially recovered from the symptoms within a

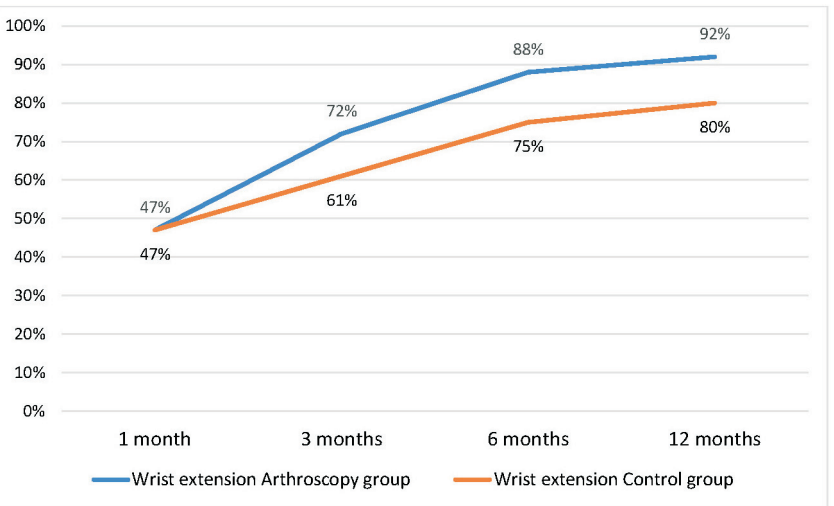

Fig. 4. Dynamic wrist extension goniometry. 


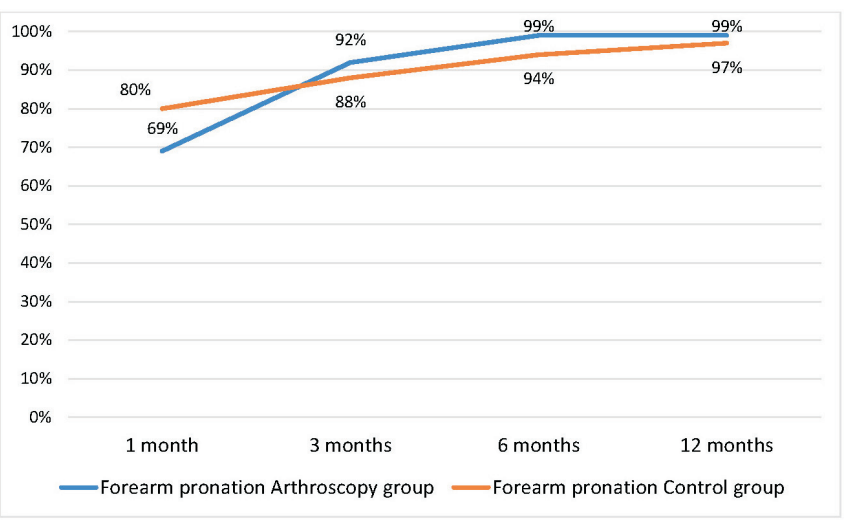

Fig. 5. Dynamic forearm pronation goniometry.

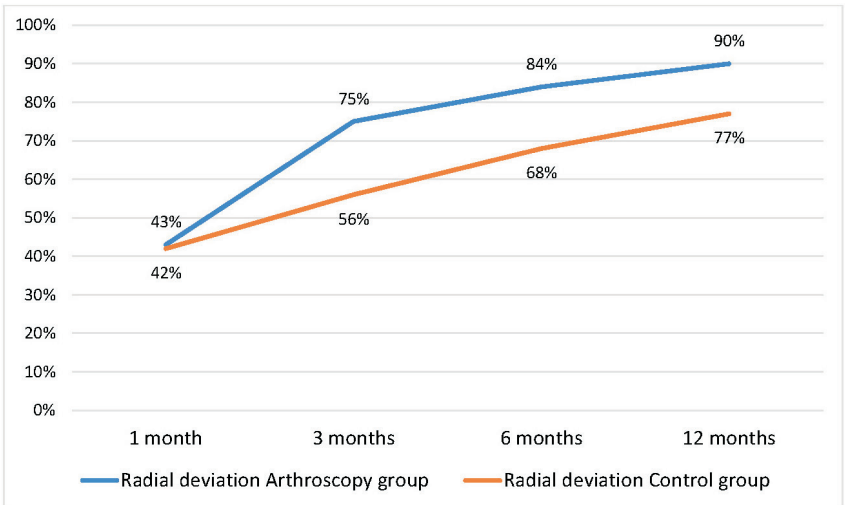

Fig. 6. Dynamic radial deviation goniometry.

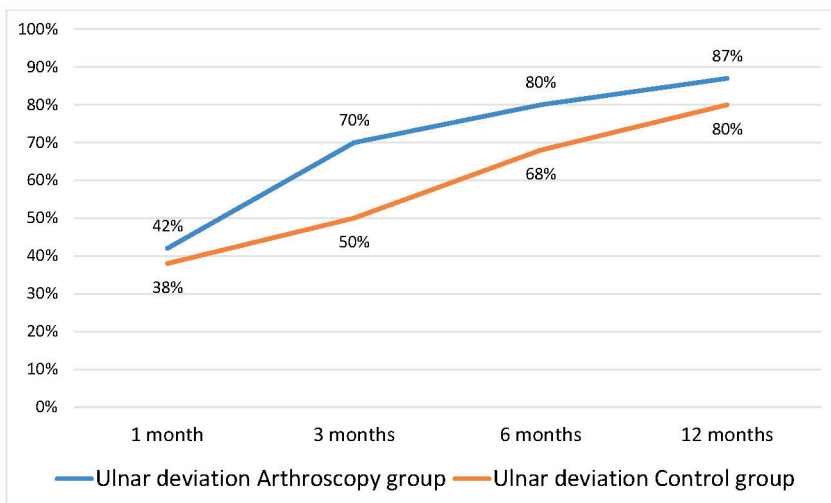

Fig. 7. Dynamic ulnar deviation goniometry.

period of six months after the surgery. Three of the 33 patients $(9 \%)$ in the arthroscopically assisted group experienced minimal migration of $\mathrm{K}$-wires and skin irritation, while in control group only one similar complication was recorded $(3 \%)$. None of patients suffered tendon ruptures, hardware migration, infections or post-operative scar problems during the observation period and even later.

\section{DISCUSSION}

The age distribution in both groups confirmed the fact that more often younger males and elder females suffer from comminuted articular distal radius fractures - the first ones because of different sports activities or even extreme activities and the second ones because of decreased bone density.
Our results using arthroscopy to visualise fragment position following preliminary reduction confirm the worth of this method in the treatment of articular distal radius fractures. Fluoroscopy alone provides an image that has poorer resolution than that of the magnified camera used for direct arthroscopic visualisation, whereas even a small degree of displacement is obvious arthroscopically (Lutsky et al., 2008). Edwards et al. (2001), performed arthroscopic examinations of the radiocarpal joint after closed reduction and percutaneous pinning in 15 patients. They found an articular displacement of $1 \mathrm{~mm}$ or more in $33 \%$ of their patients. In our arthroscopic group we found the incidence of additional fragment re-adjustment and fixation in 20 cases (56\%). More severely comminuted and higher energy injuries are more likely to require readjustment (Auge and Velazquez, 2000). Our incidence of reposition of fragments at arthroscopy was higher than found in the literature (Ono et al., 2010; Ono et al., 2012; Khanchandani and Badia, 2013; Abe and Fujii, 2017; Burnier et al., 2018).

The frequency of additional soft tissue injuries significantly differed between the two groups. It is obvious that optical visualisation of the articular space gives an opportunity to detect a greater number of soft tissue lesions more often than only fluoroscopic and clinical evaluation or surgeons mistrust about the possibilities of such injuries. Arthroscopic surgeries were longer than surgeries in the control group, but it depended also on the complexity of the fracture.

Radiological findings are presented in Table 2. There were no significant differences between radiological outcomes in both groups except that there were more arthritic or sclerotic changes of the distal radius joint surface presented in the control group.

All patients achieved a recovery to over $85 \%$ of contralateral grip strength by six months and most had achieved over $90 \%$ of contralateral grip strength by this time. None of our patients suffered any extensor tendon or flexor pollicis longus ruptures, which are commonly described complications in the literature. Final X-rays confirmed that the implants we used for fracture fixation maintained the achieved position and fragment stabilisation without any possible complications (Joseph and Harvey, 2011; Richard et al., 2011; Mehrzad and Kim, 2016).

The benefits of this study were that all surgeries were performed by the same hand surgeon, and all patients were advised to use the same post-operative rehabilitation programme guided by the same hand therapist. Post-operative evaluation was well balanced, using three different objective and subjective evaluation scores as well as X-ray controls performed in the same clinic.

As a limitations of this study, the decision to perform the surgery with volar locking plate was made by the surgeon, based on the fracture pattern and his experience and this inevitably led to selection bias. Not all of the patients later re- 
turned to the scheduled visits, and thus their outcomes were not available.

The outcomes do not establish absolute evidence for preference of one method over the other in a long period, but there were statistically significant differences in several parameters - extension, radial and ulnar deviation during the first 12 months after the surgery with better results in the arthroscopically assisted group. Furthermore, additional soft tissue injuries can be precisely diagnosed and treated, if necessary, only during the arthroscopic part of the surgery. Arthroscopic treatment of distal radius fractures is feasible in all types of articular comminution, but the one who does it must be experienced and well equipped to achieve the best possible fragment fixation.

\section{CONCLUSION}

Arthroscopic evaluation allows to determine associated soft tissue lesions and to find malposition of the intraarticular fracture fragments, which cannot be determined fluoroscopically and creates preconditions for better functional results. Since the arthroscopic group of patients consisted of a greater number of comminuted (AO C type) fractures and final functional results were equal to the results of the control group, this can indirectly indicate the benefits of the arthroscopically assisted surgery. Furthermore, patients in the "no arthroscopy" group had more arthritic or sclerotic changes of the distal radius joint surface in the long-term period. We recommend arthroscopically assisted surgery for any kind of articular distal radius fractures for any active patient in any group of age.

\section{REFERENCES}

Abe, Y. (2014). Plate presetting and arthroscopic reduction technique (part) for treatment of distal radius fractures. Handchir. Mikrochir. Plast. Chir., 46, 278-285.

Abe, Y., Fujii, K. (2017). Arthroscopic-assisted reduction of intra-articular distal radius fracture. Hand Clin., 33, 659-668.

Auge, W. K., 2nd, Velazquez, P. A. (2000). The application of indirect reduction techniques in the distal radius: The role of adjuvant arthroscopy. Arthroscopy, 16, 830-835.

Burnier, M., Le Chatelier Riquier, M., Herzberg, G. (2018). Treatment of intra-articular fracture of distal radius fractures with fluoroscopic only or combined with arthroscopic control: A prospective tomodensitometric comparative study of 40 patients. Orthop. Traumatol. Surg. Res., 104, 89-93.

Del Pinal, F. (2011). Technical tips for (dry) arthroscopic reduction and internal fixation of distal radius fractures. J. Hand Surg. Amer., 36, 1694-1705.

Doi, K., Hattori, Y., Otsuka, K., Abe, Y., Yamamoto, H. (1999). Intra-articular fractures of the distal aspect of the radius: Arthroscopically assisted reduction compared with open reduction and internal fixation. J. Bone Joint Surg. Amer., 81, 1093-1110.

Esposito, J., Schemitsch, E. H., Saccone, M., Sternheim, A., Kuzyk, P. R. (2013). External fixation versus open reduction with plate fixation for distal radius fractures: A meta-analysis of randomised controlled trials. Injury, 44, 409-416.

Franceschi, F., Franceschetti, E., Paciotti, M., Cancilleri, F., Maffulli, N., Denaro, V. (2015). Volar locking plates versus k-wire/pin fixation for the treatment of distal radial fractures: A systematic review and quantitative synthesis. Brit. Med. Bull., 115, 91-110.

Freeland, A. E., Geissler, W. B. (2000). The arthroscopic management of intra-articular distal radius fractures. Hand Surg., 5, 93-102.

Joseph, S. J., Harvey, J. N. (2011). The dorsal horizon view: Detecting screw protrusion at the distal radius. J. Hand Surg. Amer., 36, 1691-1693.

Jupiter, J. B., Marent-Huber, M., Group LCPS. (2009). Operative management of distal radial fractures with 2.4-millimeter locking plates. A multicenter prospective case series. J. Bone Joint Surg. Amer., 91, 55-65.

Khanchandani, P., Badia, A. (2013). Functional outcome of arthroscopic assisted fixation of distal radius fractures. Indian J. Orthop., 47, 288-294.

Koo, O. T., Tan, D. M., Chong, A. K. (2013). Distal radius fractures: An epidemiological review. Orthop. Surg., 5, 209-213.

Krustins, U., Krustins, J., Bringina, D., Laurane, K., Jumtins, A. (2020). Comparison of volar locking plates with external fixation and k-wires in arthroscopically assisted intra-articular distal radial fracture fixation. $J$. Hand Surg. Eur., 45 (4), 333-338.

Lutsky, K., Boyer, M. I., Steffen, J. A., Goldfarb, C. A. (2008). Arthroscopic assessment of intra-articular distal radius fractures after open reduction and internal fixation from a volar approach. J. Hand Surg. Amer., 33, 476-484.

Matschke, S., Marent-Huber, M., Audige, L., Wentzensen, A., Group LCPS. (2011). The surgical treatment of unstable distal radius fractures by angle stable implants: A multicenter prospective study. J. Orthop. Trauma, 25, 312-317.

Mehrzad, R., Kim, D. C. (2016). Complication rate comparing variable angle distal locking plate to fixed angle plate fixation of distal radius fractures. Ann. Plast. Surg., 77, 623-625.

Ono, H., Furuta, K., Fujitani, R., Katayama, T., Akahane, M. (2010). Distal radius fracture arthroscopic intraarticular displacement measurement after open reduction and internal fixation from a volar approach. J. Orthop. Sci., 15, 502-508

Ono, H., Katayama, T., Furuta, K., Suzuki, D., Fujitani, R., Akahane, M. (2012). Distal radial fracture arthroscopic intraarticular gap and step-off measurement after open reduction and internal fixation with a volar locked plate. J. Orthop. Sci., 17, 443-449.

Richard, M. J., Wartinbee, D. A., Riboh, J., Miller, M., Leversedge, F. J., Ruch, D. S. (2011). Analysis of the complications of palmar plating versus external fixation for fractures of the distal radius. J. Hand Surg. Amer., 36, 1614-1620.

Ruch, D. S., Vallee, J., Poehling, G. G., Smith, B. P., Kuzma, G. R. (2004). Arthroscopic reduction versus fluoroscopic reduction in the management of intra-articular distal radius fractures. Arthroscopy, 20, 225-230.

Sander, A. L., Leiblein, M., Sommer, K., Marzi, I., Schneidmuller, D., Frank, J. (2018). Epidemiology and treatment of distal radius fractures: Current concept based on fracture severity and not on age. Eur. J. Trauma Emerg. Surg., 46 (3), 585-590.

Selles, C. A., Mulders, M. A. M., Colaris, J. W., van Heijl, M., Cleffken, B. I., Schep, N. W. L. (2020). Arthroscopic debridement does not enhance surgical treatment of intra-articular distal radius fractures: A randomized controlled trial. J. Hand Surg. Eur., 45 (4), 327-332.

Shukla, R., Jain, R. K., Sharma, N. K., Kumar, R. (2014). External fixation versus volar locking plate for displaced intra-articular distal radius fractures: A prospective randomized comparative study of the functional outcomes. J. Orthop. Traumatol., 15, 265-270.

Souer, J. S., Ring, D., Matschke, S., Audige, L., Maren-Hubert, M., Jupiter, J. (2010). Comparison of functional outcome after volar plate fixation with 2.4-mm titanium versus 3.5-mm stainless-steel plate for extra-articular fracture of distal radius. J. Hand Surg. Amer., 35, 398-405.

Varitimidis, S. E., Basdekis, G. K., Dailiana, Z. H., Hantes, M. E., Bargiotas, K., Malizos, K. (2008). Treatment of intra-articular fractures of the distal radius: Fluoroscopic or arthroscopic reduction? J. Bone Joint Surg. Brit., 90, 778-785. 
Von Recum, J., Matschke, S., Jupiter, J. B., Ring, D., Souer, J. S., Huber, M., Audigé, L. (2012). Characteristics of two different locking compression plates in the volar fixation of complex articular distal radius fractures. Bone Joint Res., 1, 111-117.

Wilcke, M. K., Abbaszadegan, H., Adolphson, P. Y. (2011). Wrist function recovers more rapidly after volar locked plating than after external fixation but the outcomes are similar after 1 year. Acta Orthop., 82, 76-81.

Williksen, J. H., Frihagen, F., Hellund, J. C., Kvernmo, H. D., Husby, T. (2013). Volar locking plates versus external fixation and adjuvant pin fixation in unstable distal radius fractures: A randomized, controlled study. $J$. Hand Surg. Amer., 38, 1469-1476.

Received 28 July 2020

Accepted in the final form 4 February 2021
Wright, T. W., Horodyski, M., Smith, D. W. (2005). Functional outcome of unstable distal radius fractures: Orif with a volar fixed-angle tine plate versus external fixation. J. Hand Surg. Amer., 30, 289-299.

Xie, X., Xie, X., Qin, H., Shen, L., Zhang, C. (2013). Comparison of internal and external fixation of distal radius fractures. Acta Orthop., 84, 286-291.

Yamazaki, H., Uchiyama, S., Komatsu, M., Hashimoto, S., Kobayashi, Y., Sakurai, T., Kato, H. (2015). Arthroscopic assistance does not improve the functional or radiographic outcome of unstable intra-articular distal radial fractures treated with a volar locking plate: A randomised controlled trial. Bone Joint J., 97-B, 957-962.

\section{FLUOROSKOPISKI UN ARTROSKOPISKI ASISTĒTU SPIEĶKAULA DISTĀLO GALU ARTIKULĀRO LŪZUMU ĀRSTĒŠANAS METOŽU SALĪDZINĀJUMS}

Rakstā atspoguḷoti retrospektīva pētījuma rezultāti, kurā tika izvērtēti 70 pacienti ar AO-C tipa intraartikulāriem spieķkaula distālā gala lūzumiem, kuri tika ārstēti ar artroskopiski asistētu vai tikai fluoroskopiski asistētu metodi, lūzumu fiksējot ar volāro bloḳēto plāksni. Trīsdesmit septiņi pacienti tika ārstēti tikai fluoroskopijas kontrolē un 33 pacienti — artroskopiski asistētās operācijās. Pētījumā tika izmantoti to abu grupu pacientu dati, kuri apmeklēja pilnu pēcoperācijas rehabilitācijas ciklu pirmajā gadā un atsaucās vēlīno rezultātu monitorēšanai 1 līdz 5 gadus pēc operācijas. Pēcoperācijas datu analīze tika veikta, izmantojot rentgenogrāfiju, klīnisko datu apstrādi, $P a$ tient-Rated Wrist Evaluation score, Gartland and Werley, Modern Activity Subjective Survey of 2007 score pierakstus, kustību apjoma, satvēriena spēka, pincetes tvēriena un trīs pirkstu tvēriena spēka mērījumus 1, 3, 6 un 12 mēnešus pēc operācijas. Neraugoties uz vairākām statistiski ticamām atšķirībām dažādos mērījumos pēcoperācijas periodā, ilgtermiṇā klīniski nozīmīgas atškirīibas starp abām pētījuma grupām netika konstatētas. Artroskopiski asistēto operāciju grupā tika novērots lielāks plaukstas ekstenzijas un ulnāri radiālās deviācijas kustību apjoms. Operācijas laiks bija garāks artroskopiski asistētajās operācijas, taču šajā grupā bija arī lielāks šḳembaino, multifragmentāro, jeb AO-C3 tipa lūzumu. Artroskopiski asistēto operāciju grupā tika konstatēts viens kompleksā reǵionālā sāpju sindroma gadījums, turpretī kontroles grupā tādi bija divi. Nevienam pacientam netika konstatēta metāla konstrukciju migrācija, cīpslu bojājumi vai infekcijas. 